\title{
SAAMA-VERB GRAMMATILISTES KONSTRUKTSIOONIDES
}

\author{
ILONA TRAGEL, KÜLLI HABICHT
}

$\mathrm{V}$ erb saama on eesti keeles üks polüseemsemaid. Oleme varem Keeles ja Kirjanduses kirjeldanud semantilisi kategooriaid, mida selle verbiga eesti kirjakeeles väljendatakse. ${ }^{1}$ Siinses artiklis tulevad vaatluse alla grammatilised kategooriad, mida saama-abiverb konstruktsioonis infiniitse põhiverbiga väljendada võimaldab. Lähtume eeldusest, et grammatilised kasutusjuhud on välja kujunenud kesksete leksikaalsete kasutusmustrite põhjal ning on nendega grammatiseerumise kaudu seotud (vt Hopper 1991; Heine, Kuteva 2002). Niisiis läheneme saama grammatiliste kasutusjuhtude kujunemisele kui grammatisatsiooniprotsessile, püüdes visandada grammatisatsiooniahela, mis kulgeb konkreetsetest (leksikaalsetest) abstraktsemate (grammatiliste) kasutuste suunas ning ühendab eri tüüpi ja eri grammatiseerumisastmel kasutusi. Grammatisatsiooniahela kirjeldamisel lähtume konstruktsioonidest kui vormi ja tähenduse kindlapiirilistest tervikutest. Jälgime saama grammatiliste kasutusmustrite puhul ka võimalikke kontaktimõju ilminguid. Modaaltähenduste eristamisel lähtume põhiliselt Johan van der Auwera ja Vladimir Plungiani vajalikkuse ja võimalikkuse liigitusel põhinevast modaalsuskäsitlusest (1998). Siinse kvalitatiivse uurimuse materjal pärineb Tartu Ülikooli vana kirjakeele korpusest, eesti kirjakeele korpusest, eesti murrete korpusest ning veebilehtede korpusest etTenTen.

\section{1. saama modaalkonstruktsioonides}

Maailma keelte grammatisatsioonileksikonis (Heine, Kuteva 2002) on allikmõistel GET ('to get', 'to receive', 'to obtain') palju sihtmõisteid, millest viis kuulub modaalsesse valdkonda: võIMELISUs (täpsemalt: osalejasisene võIMALIKKUs), KOHUSTUS (VAJALIKKUS), LUBAMINE/VõIMALDAMINE (PERMISSIIVSUS), VÕIMALIKKUS (täpsemalt: osalejaväline võIMALIKKUs) ja õNNESTUMINE. Neist kõik peale PERMISSIIVSUSE on olemas ka eesti keele verbil saama. ${ }^{2}$

Läänemeresoome keelte $s a a$-tüve tavalisim tähendus on 'võimeline, suuteline olema' (Saukkonen 1966; Kangasniemi 1992; vt ka Habicht, Tragel 2014). Heikki Kangasniemi (1992: 329) toob saa-tüve kohta Pauli Saukkose (1966)

\footnotetext{
${ }^{1}$ Verbiga saama väljendatud leksikaalsed kategooriad ja konstruktsioonid. - Keel ja Kirjandus 2014, nr 11, lk 826-844; vt ka Tragel, Habicht 2012.

${ }^{2}$ Eesti keele permissiivkonstruktsioon hõlmab kaht sündmust, ja konstruktsiooni tähenduse võiks kokku võtta 'kedagi oma autoriteediga midagi tegema mõjutama nii, et lõplik kontroll soorituse üle on tegevuse sooritajal'. Tegu on lubamist, võimaldamist, teha laskmist väljendava konstruktsiooniga, mida tüüpiliselt vormistavad verbid andma, käskima, laskma, lubama, paluma, võimaldama. (Klettenberg 2007: 3-4)
} 
andmed: selle tüve omandamise tähendust väljendav vaste esineb läänemeresoome keeltele lisaks ka saami keeles ja mõnes uurali keeles. Saukkonen (1966) esitab oletuse, et konstruktsiooni saada + infinitiiv praegused tähendused võivad olla arenenud konstruktsioonist saa- $+\mathrm{O}+\mathrm{V}_{\mathrm{da}}$, nt saan kalaa

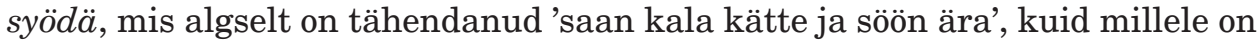
lisandunud tähendus 'ma sain võimaluse kala süüa' (Saukkonen 1966). Sellistest tähendustest oli lihtne tuletada osalejavälise võimalikkuse tähendus 'ma sain (välisoludest tingitud võimaluse) kala süüa', sest tähendas ju kala kättesaamine seda, et jumalad olid olnud armulised ja saatnud toitu. (Vt ka Tragel 2007)

Mati Erelti (2003: 106-107) andmetel on saama kolmest eesti keele kesksest modaalverbist (teised on võima ja pidama) kõige vähem grammatiseerunud ning seda kasutatakse eelkõige võimalikkuse (võimelisuse) väljendajana, harvem mittetahtlike situatsioonide kirjeldamiseks üldistes väidetes. saamaverbi grammatiseerumist, selle poolabiverbilisust ja keskseid modaalkasutusi käsitleb Erelt oma eesti keele lauseõpetuse öeldise ülevaates (2013: 117-119).

Petar Kehayov ja Reeli Torn-Leesik (2009: 368) on eesti saama-verbi modaaltähendusi käsitlenud teiste soome-ugri keelte modaalverbidega võrreldes ja toonud kõigis soome-ugri keeltes esilduvatena välja võimalikkuse ja vajalikkuse tähenduse, rõhutades viimase esinemist piiratumal alal. Kehayovi ja Torn-Leesiku (2009: 371) kriteeriumide kohaselt on saama-verbil suur polüfunktsionaalsuse potentsiaal, kuivõrd see väljendab eesti, soome ja liivi keeles viit modaalset funktsiooni.

Tänapäeva eesti kirjakeeles väljendavad saama-modaalkonstruktsioonid peamiselt osalejavälist mittedeontilist modaalsust (võimalikkus), vähem esineb osalejasisest modaalsust (võimelisus). Selle põhjuseks on peetud sobivate, st ainult osaleja sisemisest ressursist sõltuvate situatsioonide harvemat väljendamise vajadust osalejavälise võimalikkusega võrreldes. saama-konstruktsioon on tänapäeva kirjakeeles ennekõike mittedeontilise mitteepisteemilise modaalsuse väljendamise vahend. (Penjam 2008: 133) Eesti murretes on kesksetena nimetatud saama $+\mathrm{V}_{\text {tud }}$ passiivi-, impersonaali-, resultatiivsus- ja possessiivse perfekti konstruktsioone ning saama $+\mathrm{V}_{\mathrm{da}}$ impersonaali- ja modaalkonstruktsioone. Seevastu tulevikukonstruktsioone saama $+\mathrm{V}_{\mathrm{ma}}$ on murretes vähe (Uiboaed 2013).

Vanema kirjakeele andmestiku põhjal võiks eeldada, et modaaltähendused on arenenud tüüpilist grammatiseerumisteed pidi juurmodaalsustest (osalejasisesest ja osalejavälisest vÕIMALIKKUSEST ja VAJALIKKUSEST) episteemilise modaalsuse (episteemilise võIMALIKKUSE ja TÕENÄOSUSE) suunas. Eesti vanemas kirjakeeles hakkab aga seoses saama-modaalkonstruktsioonidega silma omapärane kasutustava: väga vähe näiteid leidub seal osalejasisese võIMALIKKuSE ja osalejavälise vAJALIKKUSE väljendamise kohta. Samal ajal on rohkesti näiteid episteemilise võIMALIKKUSE ja VAJALIKKUSE ning ka TULEVIKU väljendamise kohta. Seda võib seletada kontaktimõjulise grammatiseerumisega, millest on kirjutanud ka Bernd Heine ja Tania Kuteva (2003, 2005) ja mille kohaselt võib kontaktkeele tugev mõju suunata vastuvõtva keele grammatika kujunemist nii, et loomulikus grammatiseerumises jäetakse astmeid vahele (vt Habicht 2001: 168; Metslang 2011). Saksa keele mõju tingimustes on eesti varasemas kirjakeeles üle võetud kaugemale grammatiseerunud konstruktsioon: TõENÄOSUSE väljendamine saama-konstruktsiooni abil ja järgmise arengujärguna ka TULEvIK. Need on olnud religioossete tekstide tõlkimisel vajalikud konstruktsioonid, 
mis on keelekorralduslike seisukohtade muutumisest põhjustatud tõusude ja mõõnadega kasutusel olnud XVII sajandist alates kuni tänapäevani.

saama-modaalkonstruktsioonid, mille struktuur, kaasa arvatud põhiverbi infinitiivivormi valik, varieerub XVII sajandi kirjakeeles märkimisväärselt, on vanemas kirjakeeles sagedased. Kui XVI sajandist ja XVII sajandi algusest pärinevates tekstides ei leidu näiteid võimalikkuse ja vajalikkuse kohta, mida oleks väljendatud saama-konstruktsiooni abil, siis leidub selliseid näiteid juba XVIII sajandi tekstides, kus taotleti teadlikult suuremat rahvakeelelähedust. Tõsi, ka XVII sajandi algul kirja pandud Georg Mülleri käsikirjalistes jutlustes esineb neljal korral konstruktsioon nägema saama 'nägijaks saama', mis võib osutada, et rahvakeeles on sellel võimelisuse > võimalikkuse tähendus olemas olnud. Selline kasutusviis näitab ühtlasi loomulikku grammatiseerumist, mis peegeldab tugeva saksa kontaktimõju eelset seisu ja avab saama + $\mathrm{V}_{\mathrm{ma}}$ konstruktsiooni varasema kasutuse, mis seostub leksikaalselt tähenduselt muutumisega (vrd muutuskonstruktsiooni nägijaks saama). Olukord teiseneb aga juba XVII sajandi 30. aastatel, mil saksamõjuline keelekasutus muutub standardiks ning saksa werden-abiverbi tõlkevastena hakatakse järjest rohkem kasutama saama-futuurumi konstruktsioone. Need on tavapärased nt Heinrich Stahli, XVII sajandi eesti kirikukirjakeele algusperioodi enim mõjutanud autoriteetse misjonilingvisti keelekasutuses:

(1) NJnck tehhet sahwat sündima sest pehwalickust / ninck kuhst / ninck techtest / ninck mah pehl sahp selle rahwalle werriseminne olla/ ninck sahwat wabbisema / ninck se merri ninck needt merrewohdt sahwat murrisema .. VNd es werden Zeichen geschehen an der Soñen / vñd Mond / vnd Sternen / Vnd auff Erden wird den Leuten bange sein / vnd werden zagen / Vnd das Meer vnnd die Wasserwogen werden brausen .. (VAKK, Stahl 1638, HH III, 4) 'Ning tunnustähed sünnivad päikesest, kuust ja tähtedest ning maa peal on inimestel hirm ja nad vabisevad ning meri ja merevood mürisevad'

Eelnevas näites on ühelt poolt näha saksa futuurumivormi täpset vastavusse seadmist eesti keele saama-konstruktsioonidega. See on XVII sajandi tõlkelise kirjakeele ilming, mis osutab sellele, et võõramaalastest pastoritele mõeldud tekstides eelistasid mitte-eestlastest autorid eestikeelses tekstis saksa keelega võrreldavaid konstruktsioone. Teisalt ilmneb näitelauses ka Stahli vormivaliku eripära: ta kasutab saama-konstruktsioonis enamiku põhiverbidega $m a$-infinitiivi, ühel juhul, koos olema-verbiga, aga $d a$-infinitiivi. Ilmselt oli selle varieerimise taustaks autori isikupärane vormitaju, sest lisaks olema-verbile on sarnastes konstruktsioonides erandlikult ja küllaltki süsteemselt $d a$-infinitiivi vormis kasutatud ka minema- ja tulema-verbi. Ei ole siiski alust arvata, et Stahl tõlgendanuks $m a$ - ja $d a$-infinitiivilist kasutust sarnases konstruktsioonis eri funktsioonidena.

Tänapäeva eesti keeles on eri tüüpi modaalkonstruktsioonidega seotud erinevad infinitiivivormid: $d a$-infinitiiviga vormistatakse osalejasisest (2) ja osalejavälist (3) ning episteemilist võImALIKKust 'vähene tõenäosus' (4), mainfinitiiviga RESULTATIIVSUST, mis on seotud õNNESTUMISE tähendusega (5), ja TULEVIKKU (6).

(2) Aga loomekomplektiga saab koos mängida. (etTenTen, www.poogen.ee) 
(3) Ega sa lihtinimese ja töölisena ei saagi peale oma valimise hääle suurt teha. (etTenTen, www.mulje.ee)

(4) Tegelikult ei olnud tema jaoks väljaspool kehalist olekut millelgi mõtet, nagu saaks inimene ja loom ilma kehata üldse olemas olla. (N717 ILU)

(5) .. TÜ/Rock sai oma vankri õigesti jooksma alles teise veerandaja keskel. (basket.ut.ee)

(6) See saab olema üks suur lust ja lillepidu kui siniste päevadega midagi jukerdama hakatakse. (etTenTen, happy.net.ut.ee)

Eesti murretest puudub senini täpsem ülevaade saama erinevate modaalkasutuste jagunemise kohta, ${ }^{3}$ kuid korpusematerjalis on rohkesti just osalejasisese võimalikkuse näiteid, nt

(7) mull jalad vigasest jäänuvad *ei saa `kõn'dida* (ÄKS)

\subsection{Võimalikkusmodaalsus}

Eesti vanemas kirjakeeles leiduvad esimesed osalejavälise mittedeontilise võIMALIKKUSE näited XVII ja XVIII sajandi kirjakeeles. Verb saama on oleviku ainsuse 3. pöörde vormis, nt

(8) Küllab siis otse mönnusad sannad saab selle ue Testamenti ramato sees luggeda. (VAKK, Helle 1732, 386)

Näiteid osalejasisese ja osalejavälise võIMALIKKUSE vahealalt leidub ka XIX sajandi tekstides.

(9) kas seddasinnast önsat ello kegi siin pärrida saab? (VAKK, Holtz 1817, 116)

(10) Kül oli temal karta waewa ja häda teadmatagi, kas enam elusalt pöörab tagasi ja saab omastega röömustada! (VAKK, Schüdlöffel 1844, 11)

Osalejavälise deontilise võIMALIKKusE näiteid leidub osalejasisese mittedeontilise võIMALIKKUSEGA võrreldes oluliselt vähem. Vana kirjakeele materjalis see funktsioon ei esildunud, kuigi täpsem korpuseanalüüs võiks ilmselt mõne seda tüüpi haruldasema kasutusjuhu välja tuua. Osalejavälist deontilist võIMALIKKUST tänapäevases kasutuses ilmestab näide 11 .

(11) Loomist ja hävitamist, rumalust ja tarkust, armastust ja vihkamist ei saa kuulutada „võrdselt õigeiks”. (etTenTen, www.ekspress.ee)

Eesti vanemas kirjakeeles leidub vaid üksikuid osalejavälise deontilise võIMALIKKUSE näiteid, mis sisaldavad viidet deontilisele autoriteedile, kes midagi võimalikuks teeb. Esimesed sellised kasutusjuhud leiduvad XVIII sajandi esimese poole tekstides, piiblikeele teadliku rahvapärastamise ajal, nt

(12) .. sest nemmad nutwad minno ees ja ütlevad: Anna meile lihha, et same süa.

(VAKK, Piibel 1739, 4Ms 11:13)

${ }^{3}$ Kristel Uiboaed ei ole doktoritöös (2013), mis analüüsib ka murretes esinevaid saamakonstruktsioone, eri modaaltähendustel vahet teinud. 
Võimalikkuskonstruktsioon on võinud oma arengus lähtuda omandamiskonstruktsiooni laienduseks tõlgendatavatest kognitiivverbide $d a$-infinitiivi vormis kasutusjuhtudest, mida leidub ka varasemas kirjakeeles (vt ka Habicht, Tragel 2014: 833-836), nt

(13) Kes ütlevad: Tötko Juñal, ta tehko ruttuste omma tö, et same nähha; ja sago liggi, ja tulgo waid Israeli pühha Lunnastaja nou, et same teäda. (VAKK, Piibel 1739, Js 5:19)

Ka tud-partitsiibiga saama-konstruktsioon väljendab osaleja võimelisust millegi tegemiseks välistest või sisemistest takistustest hoolimata. Selliselt on vanemas rahvakeeles väljendatud osalejasisest võIMALIKKUST. Samal ajal on konstruktsioon seotud ka üldisema õNNESTUMISE ja RESULTATIIVSUSE tähendusega. Tänapäeva kirjakeeles neid konstruktsioone niisuguses funktsioonis ei kasutata.

(14a) Kas sa saad kaa söödud oma hamba-waluga? (Ahrens 1853)

(14b) möni saab nönda oldud ('tal on võime nii olla') (Ahrens 1853)

Võimalikkuskonstruktsioonidest on toimunud grammatiseerumine VAJALIKKUSE väljendamise suunas.

\subsection{Vajalikkusmodaalsus ja modaaltähenduste piiritlemise probleemid}

Tänapäeva kirjakeeles võib saama-modaalkonstruktsioon lisaks osalejasisesele ja osalejavälisele võIMALIKKUSELE väljendada ka VAJALIKKUST, nagu on osutanud mh Kehayov ja Torn-Leesik (2009) ning Pille Penjam (2008: 133). Sellise tähendusega konstruktsioon on domineeriva võimalikkuskonstruktsiooni kõrval siiski harv ning VAJALIKKUSE tähendus järeldub sellistel juhtudel kontekstist ega ole tõlgenduslikult ühemõtteline, nt

(15) Teie saate veel kaua-kaua tema eest hellalt hoolitseda, võite õrnusevarud tervenisti mängu panna. (Penjam 2008: 133)

Piir osalejasisese ja osalejavälise võIMALIKKUSE väljendamise vahel on hajus ning kirjakeeles leidub hulgaliselt sildkontekste, kus on võimalikud mõlemad tõlgendused, nt

(16) Se olli õ’nnega kóus, kes surnud hobbose küllest tükki lihha sai lõigata ja sedda omma jahhodega kéta. (VAKK, Suve Jaan 1841, 1344)

Eelneva lause sisu on võimalik tõlgendada nii osalejasisesest võIMELISUSEST, st osaleja tegutsemisvalmidusest, kui ka osalejavälisest võIMALIKKUSEST, st soodsate (välis)tingimuste olemasolust lähtudes.

Verbi saama modaalkasutustele on iseloomulik ka see, et kõnelejal on võimalus jätta täpsem tõlgendus lahtiseks. Näite 17a kontekstist ei selgu, mis on selle põhjuseks, et kassiga ei saa õnnelik olla (st kas põhjus on seisukoha autoris või kassis). Näites $17 \mathrm{~b}$ on keelekasutaja väljendanud end saama-verbiga, kuigi saanuks valida ka selgemalt näiteks keeldu väljendavad vahendid 
(ei või / ei tohi). Selline valik võib osutada, et kuigi lauset saab mitmeti mõista, on esiplaanil ikkagi osalejavälise võIMALIKKUSE tõlgendus.

(17a) Sest kassiga Ei Saa olla õnnelik. (etTenTen, pilleriin.ee)

(17b) See ei saa nii olla! (etTenTen, www.mulje.ee)

Veelgi komplitseeritum on modaalsuse liiki määratleda nn üldisikulistes näidetes (saama-verb ainsuse 3. pöördes), milles ei ole selge isegi modaalsuse agent. Näide 18a võiks kuuluda episteemilise modaalsuse valdkonda, st see väljendab kõneleja järeldust situatsiooni parameetrite põhjal. Oleme seisukohal, et sarnaselt Eve Sweetseri modaalsuskäsitlusega (1990) on ka eesti keele saama-verbi modaaltähendusi analüüsides mõttekas vaadata episteemilist modaaltähendust juurmodaalsusest pärinevana ja sellega seotuna. Sweetser ongi seda käsitlenud metafoorse ülekandena sotsiaalse (vrd osalejaväline VÕIMALIKKUS ja vAJALIKKUS) ja füüsilise/vaimse (vrd osalejasisene võIMALIKKUS) modaalsuse valdkonnast (ehk juurmodaalsusest) järeldustasandi (ingl reasoning) valdkondadesse (episteemiline modaalsus) (Sweetser 1990: 59). Järeldustasandi kasutuste tõlgendamisel on taas oluline roll õNNESTUMISE tähendusel (18b), nt mõistestajal on raskusi Kristina nimetamisega päris-suusatajaks (täpsemalt vt Habicht, Tragel 2014: 831-833).

(18a) Kuidas sellised asjad saavad sündida? (etTenTen, www.ekspress.ee)

(18b) Verinoort Kristinat ei saanud päris-suusatajaks veel tituleeridagi, kui meedias ilmus tunnustatud ajakirjanikult kommentaar, et tüdrukust ei saa niikuinii midagi .. (etTenTen, www.ohtuleht.ee)

\subsection{Episteemiline modaalsus (TõENÄOSUS)}

Selle kohta, kuidas osalejavälise võIMALIKKusE tähendus läheb üle episteemilise VÕIMALIKKUSE ja VAJALIKKUSE tähenduseks, pakuvad vana kirjakeele tekstid vaid üksikuid näiteid:

(19) Kuida tedda keige parreminne paigale saab panna? Wie bringt man sie am füglichsten an ihrem Ort. (VAKK, Helle 1732, 395)

Episteemilise kasutusega on seotud nii vanemates (piibli- ja rahvapärastes) tekstides kui ka tänapäeva keeles kasutusel olev kinnistunud (püsiühendiline) konstruktsioon saab näha, mis viitab lisaks TõENÄOSUSELE ka TULEVIKULE, nt

(20) Agga need teised tülid: Oot/ saab nähha/ kas Elias tulleb/ ja awwitab tedda. (VAKK, UT 1715, Mt 27:49)

saama $+\mathrm{V}_{\mathrm{da}}$ konstruktsiooniga väljendatav tõenäosushinnang puudutab sellisel juhul kõrvallause sisu. XVIII sajandi tekstide põhjal otsustades on tegu püsiühendilaadse kasutusega, mis võib olla eesti keeles rahvapärane. Samal ajal leidub üksikuid näiteid näha saama vaba, st mittepüsiühendilise kasutuse kohta (ka minevikuvormis saama-verbiga) juba XVII sajandi esimese poole tekstides, nt 
(21) Waidt ny pea, kudt Esau oma Nohremba welie se Iacobe say neha .. (VAKK, Müller 1605/23, 6)

'Vaid niipea, kui Eesav sai oma nooremat venda Jaakobit näha'

TõENÄOsust väljendab saama $+\mathrm{V}_{\mathrm{da}}$ konstruktsioon ka tänapäeva keeles, kuigi sellised kasutusjuhud on harvad, nt

(22) Igasugune küberrünnak saab tõhusalt kahjustada modernset ja rahu-rütmis tuksuvat ühiskonda. (etTenTen, www.ekspress.ee)

Episteemilisest modaalkonstruktsioonist toimub grammatiseerumine tulevikukonstruktsioonide suunas, kusjuures üleminek järelduslikult tõenäosuslikkuselt tulevikulisusele ei ole selgelt piiritletav ning võib sildkontekstidena sisaldada kaheti analüüsitavaid juhtumeid (23). See ongi kontekst, mis ka vormiliselt (saama $+\mathrm{V}_{\text {ma }}$ ) sobib futuurumitõlgenduste aluseks (vt artikli 3. alajaotist).

(23) Aga Jumalale tänu, ka meie lootus kaswab, sest see aeg ei ole tõeste enam kaugel, kus selle „kedr-warre” rattad mite enam nii mõnusaste ei saa käima. (VAKK, Jakobson 1870, 43)

\section{4. saama-modaalkonstruktsiooni eituslembesus}

Tänapäeva eesti keeles esindavad korpusematerjali põhjal otsustades kõige tavalisemat saama-konstruktsiooni Johan van der Auwera ja Vladimir Plungiani (1998) liigituse alusel osalejavälise mittedeontilise mitteepisteemilise modaalsuse näited (vt Penjam 2008: 133), täpsemalt võimalikkuskonstruktsioonid (vt näiteid 2 ja 3 ).

Oluline tähelepanek saama-verbi tänapäeva eesti keeles kasutamisest puudutab vormi: varasematele käsitlustele toetudes (Tragel 2004; Penjam 2008) võib väita, et saama-verbil on võrreldes teiste modaalsete verbidega tugev kalduvus esineda eitavas vormis, eriti osalejasisese ja -välise võIMALIKKUSE ja VAJALIKKUSE konstruktsioonides. Pille Penjami materjalist selgus, et 372-st analüüsitud saama modaalsest kasutusjuhust olid 181 ( 49\%) eitavas vormis. Teiste sarnaste sagedaste verbide eitavate kasutuste osakaal on tavaliselt kõige rohkem umbes $20 \%$. Erandiks on siin vaid verbid suutma ja tohtima, mille eitavate kasutuste osakaal on isegi 80-90 \% kõikidest kasutusjuhtudest (Penjam 2008: 136).

Vaadates näiteid, mis on saama modaaltähenduste kohta välja toodud eesti keele seletavas sõnaraamatus (EKSS), leiame samuti, et kas teadlikult või intuitiivselt on koostajad valinud näitelaused nii, et 21-st osalejasisest või osalejavälist võIMALIKKUST väljendavast modaalsest näitest on 15 eitavas vormis. Alltähenduse 'tohtima, võima' viiest näitelausest on eitavad kolm.

Eitavate kasutuste sagedust on täheldatud ka eesti lastekeele uurimustes. Siinse käsitluse aluseks olevad andmed on pärit CHILDES-korpusest, kus sisaldub viie eesti lapse sarnastel tingimustel kogutud materjal. Korpusest on viiel lapsel vanuses 1;5-2;6 registreeritud verbi saama esmakasutused. Neljal lapsel viiest olid need kasutused eitavas vormis (ei saa - isikut, aega jm ei ole tavaliselt selle materjali põhjal veel võimalik üheselt määrata). Sellised kasu- 
tusjuhud, mille tähendust oli konteksti põhjal võimalik määrata, esindasid kõik negatiivset õNNESTUMisT (mitteõnnestumist). (Tragel 2003)

Eitavate kasutuste ülekaalul võib olla mitmeid põhjusi. Keeleajaloolisest ja grammatisatsiooni aspektist on näiteks ka inglise keele põhjal väidetud, et eitavates ümbrustes säilivad vanemad tähendused paremini (nt Traugott 1989: 52). Selle tendentsi kehtivust eesti keeles on siiski raske kommenteerida, sest modaaltähenduste ajalist järgnevust ei ole olemasolevate allikate põhjal võimalik täpselt määrata - saame vaid oletada, et eesti keel järgib siin universaalset grammatiseerumisskeemi.

Võimalik selgitus saama-konstruktsiooni eituslembesusele (vt ka näiteid $3,7,17 \mathrm{a}, 17 \mathrm{~b}, 18 \mathrm{~b}$ ) on see, et tegelikus suhtluses esilduvad emotsionaalse varjundiga mitteõnnestumise olukorrad. Niisiis kasutatakse verbi saama olukorra mõistestamiseks pigem siis, kui mingi tegevus ei õnnestu / ei ole võimalik / ei ole lubatud. Samas võidakse n-ö positiivse olukorra väljendamiseks kasutada eelistatult muid keelevahendeid. Laste keelekasutuses on tavaline see, et ÕNNESTUMINE ei vaja kommenteerimist, ei saa võib laste kasutuses implitseerida just seda, et nad ootavad abi oma tegevuse edukal lõpuleviimisel (vt ka Tragel 2003; Pajusalu jt 2004: 125, 127).

\subsection{Järeldused}

Niisiis on saama modaaltähenduste areng olnud konstruktsioonide sisu ja vormi arvestades keerukas ja läbipõimunud, kuid järginud siiski universaalseid grammatiseerumise seaduspärasusi, mille kohaselt on modaalkasutuste lähteks täistähenduslikud (leksikaalsed) kasutusjuhud. Areng on toimunud $\mathrm{nn}$ juurmodaalsusest tõenäosusmodaalsuse suunas ja jätkub sealt tuleviku abiverbi kujunemise poole.

Märkimist väärib asjaolu, et episteemilise vAJALIKKUSE väljendamiseks on eesti keeles kasutusel erineva infinitiivivormiga konstruktsioon ( kui episteemilise võIMALIKKUSE väljendamiseks (saama $+\mathrm{V}_{\mathrm{da}}$ ). Seega lähtub esimene neist grammatiseerumisahela sellest osast, mis läbib eelastmetena ÕNNESTUMISE ja MUUTUMISE; teine aga ahela teisest harust, kus eelastmeteks on ÕNNESTUMINE, OMANDAMINE ning osalejasisene ja -väline võIMALIKKUS.

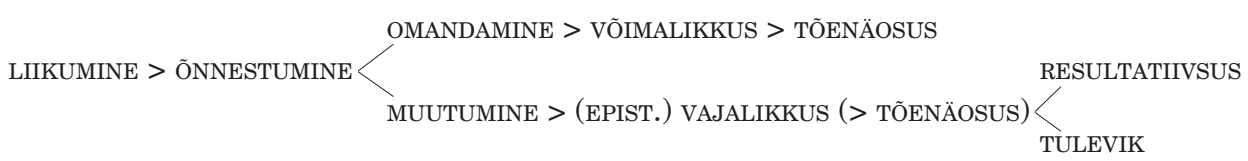

J o o n is 1. saama-verbi grammatisatsiooniahel.

\section{Resultatiivsus}

\subsection{Resultatiivne-passiivne konstruktsioon}

Resultatiivsed-passiivsed konstruktsioonid hõlmavad potentsiaalselt lõpuni jõudvaid või juba jõudnud tegevusi, mida vormistatakse saama-verbi vormi ja mineviku partitsiibi (-nud, -tud) abil. 
Meie visandatud kaheharulises grammatisatsiooniahelas moodustab muutumistähenduse kaudu metafoorse ülekande teel tekkinud resultatiivkonstruktsioon omaette arenguetapi. Mõisteliselt võiks see konstruktsioon eelneda tulevikukonstruktsioonile, kuigi selle vorm on tulevikukonstruktsioonist erinev. Ühine on neile sündmuse projitseerimine tulevikku ja resultatiivsuse potentsiaal.

Tänapäeva eesti keeles on saama + tud-partitsiibi konstruktsioonidel oma kindel koht passiivi väljendusvahendite hulgas.

Siinses käsitluses oleme kõrvale jätnud täpsemad argumentstruktuuri vormistamisega seotud süntaktilised seigad ja lähtume vaid tüpoloogiliselt määratletud GET-verbi konstruktsioonide saama-tähenduse kaudu tõlgenduvast potentsiaalist vormistada eri tüüpi grammatilisi konstruktsioone, sh resultatiivsust. Eri keelte käsitlustes on kirjeldatud saamisverbidega seonduva GET-passiivi (sh saksa bekommen-passiivi) arenemist nn saajapassiivi konstruktsiooniks, kus GET on abiverbistunud ja subjekti positsioonis ei ole mitte agent, vaid retsipient (saaja). (Vt Diedrichsen 2012: 1198, samuti Nolan 2012: 1147-1151) Ka eesti keeles on märgatavad nn GET-passiivi alged. Seda tüüpi konstruktsioonid ei ole grammatiseerunud väga kaugele, kuid neil on oma hästi eristuvate funktsioonidega kasutusala. Mati Erelt (2013: 197) esitab konstruktsiooni saama $+\mathrm{V}_{\text {tud }}$ seisundipassiivina, nt Lauad saavad kaetud.

Samadest vahenditest lähtub ka teine, mõnevõrra erinevaid morfosüntaktilisi vahendeid kasutav konstruktsioon, possessiivne perfekt, nt $\mathrm{Mul}$ on / sai kiri kirjutatud (Lindström, Tragel 2007, 2010). Kummalgi konstruktsioonil on oma spetsiifiline funktsioon: neid eristab eelkõige agendi erinev kaasatus. Näide 24a esindab nn personaalset passiivi, mida väljendab resultatiivne konstruktsioon: saama-verb personaalis ja subjektina juurdemõeldav agent. Näide 24b on possessiivse perfekti konstruktsioon, milles agent vormistatakse adessiiviga. Võrreldes verbiga olema moodustatud possessiivse perfekti konstruktsiooniga lisab saama kasutamine tähendusele dünaamilisust, samuti on tajutav ÕNNESTUMISE kaastähendus. Resultatiivne konstruktsioon on eriti ilmne juhul, kui saama-verb esineb mineviku vormis.

(24a) Sain lõpuks mähkud ka koju ostetud Pampersi Newborn 2-5 kg (etTenTen, www.nupsu.ee)

(24b) Peale pikka seletamist sain pildi kätte, aga tal sai tehtud see ülesanne, mis ma ka just äsja ära tegin. (etTenTen, www.buduaar.ee)

On huvitav tõdeda, et esimene saama-infiniittarindi grammatiline kasutus eesti kirjakeeles ongi just saama-futuurumi kohta passiivses konstruktsioonis. Et tegemist on kõrgel grammatiseerumisastmel konstruktsiooniga, on sellise kasutuse puhul ilmne saksa keele vastava konstruktsiooni eeskuju. Tegu on umbes 1600. aastast pärineva kohtuvandega, mis on tõlkelist päritolu:

(25) .. eht minna se asja sees, me perrast minnul nüht sahp küszitut sahma, se selgke n. puchta töszidusse kellekil hehx ech kahjux, welja reckima tahhan. (VAKK, kohtuvanne 1600, 1) 


\subsection{Muud resultatiivsed ja passiivsed konstruktsioonid: saama $+\mathrm{V}_{\text {nud }}$ ja saama $+\mathrm{V}_{\mathrm{da}}$}

Vanas kirjakeeles on kasutusel aktiivne konstruktsioon, mis koosneb saamaverbi oleviku- või lihtminevikuvormist ja põhiverbi nud-kesksõnast. Konstruktsioon osutab enamasti tulevikulisele resultatiivsele tegevusele (tuleviku kohta vt ka 3. alajaotust). Vanemas kirjakeeles on see konstruktsioon arvukalt esindatud ja sellisena arvatavasti ka rahvakeeles olemas olnud, nt

(26a) Agga kui teie ühhe Linna ehk Allewe sisse sate läinud/ siis küsige/ kes selle sees sedda wäärt on .. (VAKK, UT 1715, Mt 10:11)

(26b) kül ma saan seks ajaks söönud (Ahrens 1853)

Possessiivse konstruktsiooni laiendusena võib käsitada agentadverbiaaliga vormistatud passiivseid saama-konstruktsioone, kus patsient on tõstetud subjektiks ning agent, mis on lauses olemas, vormistatakse adverbiaalsena. Agentadverbiaaliks võib olla muuhulgas käest- või poolt-adpositsioonifraas (27a) või ka ablatiivis substantiivifraas (27b) (vt ka Penjam 2008: 151-153).

(27a) Ma pole vist elusees ka nii palju nõgeste käest kõrvetada saanud kui seal. (etTenTen, www.geopeitus.ee)

(27b) Oma pahameeleavalduste viisaka leebuse eest sai Uus-Meremaalt ja Austraalialt noomida ka Suurbritannia. (näide Penjam 2008: 153)

Erelt nimetab oma uusimas öeldisekäsitluses sellist saama $+\mathrm{V}_{\mathrm{da}}$ konstruktsiooni saama-tegevuspassiiviks ning osutab seoses kannatust ja proovimist ning taju ja teadmist väljendavate verbidega sisult negatiivse konstruktsiooni puhul selle seosele osalejavälise vAJALIKKUSEGA ('pidama, sunnitud olema'), positiivse situatsiooni korral aga osalejavälise võIMALIKKUSEGA ('võimalik olema') (Erelt 2013: 198).

\section{Tulevikukonstruktsioonid}

Lähtudes sellest, et saama siin visandatud grammatisatsiooniahel algab LIIKUMISE ja ÕNNESTUMISE tähendusest, saab ka tulevikukonstruktsioonide teket vaadelda nende lähtetähenduste loogilise edasiarenguna. Lisaks mainitud algsetele tähendustele võivad TULEviKU grammatilist kasutust mõjutada erinevaid füüsilisi või vaimseid seisundimuutusi väljendavad muutuskonstruktsioonid, episteemilised vajalikkuskonstruktsioonid saama $+\mathrm{V}_{\mathrm{ma}}$ ning resultatiivsed konstruktsioonid. Viimaste ja tulevikukonstruktsioonide sisuliseks ühisosaks on protsessi teostumise tõenäosuslikkus ja loodetav tulemuslikkus. Vormiline motivatsioon on $m a$-infinitiivi suunakäändelises päritolus.

Tulevikutähenduse selline kujunemiskäik on meie arvates nii sisuliselt kui ka vormiliselt motiveeritud ning järgib eesti keelt mõjutanud saksa keele werden-tuleviku kujunemise loogikat MUUTUMIST väljendavast leksikaalsest verbist abiverbiks. Tulevikukonstruktsiooni kujunemine oleks põhjendatav tähendusnihkega sarnase funktsiooni täitmiseks.

Eesti saama-verbi puhul on täidetud ka leksikaalse lähteverbi olulised tingimused: skemaatiline tähendus, suur kasutussagedus, sobivus paljudesse 
lausemallidesse, denotatiivne seos inimtunnetuses olulise ja suhtluses keskse valdkonnaga. Välistest teguritest soodustab abiverbistumist väljendusvajadus ning eeskujuks sobiva keelevahendi olemasolu kontaktkeeles (saksa keel). (Heine 1993; Metslang 1994a: 543-544)

\section{1. saama $+V_{\text {ma }}$ kasutusest kirjakeeles}

Korpusematerjali põhjal ilmneb, et saama-konstruktsioon on vanima kirjakeele perioodil, XVI sajandist kuni XVIII sajandi alguseni, kirjakeeles kasutusel kui regulaarne grammatiline konstruktsioon, mis koosneb abiverbist saama ja põhiverbi $m a$-infinitiivi vormist ning mille ülesandeks on osutada kõnehetkest hiljem toimuvale sündmusele, absoluutsele tulevikule. (Vt ka Ross 2013: 217-220)

Alates XX sajandi alguskümnenditest on saama-tulevikku kui germanismi eesti kirjakeelest teadlikult tõrjutud, kuid konstruktsioon pole siiski keelest kadunud. Kõige sagedamini esineb see tänapäeva eesti keeles koos üldises tähenduses olema-verbiga (28a), kuid leidub näiteid ka aktiivset tegevust väljendavate verbidega kasutatud saama-konstruktsioonide kohta (28b).

(28a) Mart Juur tunnistab, et arvas alguses, et see saade saab olema rohkem selline friikide sõu, nagu eesti reality-sarjad ikka .. (etTenTen, www.naisteleht.ee)

(28b) Akadeemia on teinud, teeb ja saab tegema oma parima, et teadvustada ja tähtsustada teaduspõhist õpet. (etTenTen, www.akadeemia.ee)

Võib öelda, et saama-futuurumit on eesti kirjakeeles kasutatud laineliselt. Kui esimestes eestikeelsetes kirjapanekutes leidub üksikuid sellekohaseid näiteid ja alamsaksamõjulised tekstid (nt Georg Mülleri jutlused 1600-1606) eelistavad tahtma-futuurumit, siis väga sagedaseks saavad saksa eeskujul moodustatud werden-futuurumi vormid XVII sajandi keskpaigast alates. XVII sajandi lõpust (Johann Hornungi grammatikas (1693) fikseerituna) hakkab nende konstruktsioonide osatähtsus kirjakeeles vähenema. Esimeses eestikeelses täispiiblis (1739) püütakse saama-futuurumit teadlikult vältida, ehkki üksikuid konstruktsioone, mis on ilmselt olnud rahvakeelsetega kõige sarnasemad, leidub sealgi. XVIII sajandi esimesel poolel võtsid rahvakeelelähedust väärtustavad piiblitõlkijad eesotsas Anton Thor Hellega teadlikult kasutusele rahvakeelse taustaga võtma-tuleviku. (Habicht jt 2015: 43) XVIII sajandi lõpupoole, kui suureneb tõlkelise valgustusliku kirjanduse ja ka ilukirjanduse osatähtsus, saavad saama-tuleviku konstruktsioonid taas sagedamini kasutatavaks ja juurduvad eesti kirjakeelde, nii et neid võib leida ka XIX sajandi lõpul ja XX sajandi algul kirjutanud eestlastest autorite tekstidest. Mõningane tagasilangus tabab neid konstruktsioone taas 1930. aastatel, mil neid kui germanisme soovitatakse õigekeelsuslikult vältida. Sellest hoolimata leidub saama-futuurumi näiteid nii XX sajandi teise poole kui ka XXI sajandi alguse kirjakeeles, viimasel ajal ennekõike ühendis olema-verbiga.

Maailma keeltes on tulevikuvormid sageli analüütilised ja sisaldavad mitmeid lisatähendusi võrreldes nt minevikuvormidega. Lisatähendused kannavad jälgi leksikaalsest lähtematerjalist. Tulevikust rääkimine saab olla kas kavandamine või ennustamine (Dahl 2000: 309; Metslang 1994a: 539). Niisiis võiksid saama-tuleviku leksikaalsed tausttähendused olla LIIKUMINE, ÕNNESTU- 
MINE, TÕENÄOSUs. Neid tähendusi kajastab ka meie hüpoteetiline grammatisatsiooniahel (vt joonist 1).

Helle Metslang, kes on oma uurimustes korduvalt futuurumi problemaatikat käsitlenud, jõuab järeldusele, et saama-tulevikku pole eesti keel kuigivõrd omaks võtnud ning nii keele uurijad kui ka harijad on suhtunud sellesse konstruktsiooni enamasti kui võõrmõjulisse (Metslang 1997: 227). Seda ei saa siiski öelda saab olema -tüüpi futuurumikonstruktsiooni kohta, mida leidub kirjakeeles rohkesti. Muude verbidega seoses pole konstruktsioon tõepoolest nii produktiivne (vt ka Prass 2011). Tulevikukonstruktsiooni lõplikust juurdumatusest nii vana kirjakeele perioodil kui ka tänapäeva keeles annab tunnistust see, et piir TÕENÄOSUSE ja TULEvIKU tähenduse vahel on hajus (vt näidet 23) ning kõik saama $+\mathrm{V}_{\text {ma }}$ konstruktsioonid ei saa tulevikulist tõlgendust. Sellisena kuulub saama-futuurum eesti grammatilise ajasüsteemi perifeeriasse, olemata täiesti regulaarne ajavorm. Metslangi väitel on saama-futuurum eesti kirjakeelde juurutatud sellisena, nagu oleks saama tõeline, kaugele grammatiseerunud abiverb, st futuurumi marker, milles ei ole varasemate tähenduste ja kasutuspiirangute jälgi. See ebaloomulik juurutamine sisaldabki tema arvates vastuolu, mis takistab saama-futuurumi levikut. (Metslang 1997: 228-229) Samavõrd tugev võib siin aga olla ka keelekorralduse ja keeletoimetamise mõju: saama-konstruktsioone on soovitatud normikirjakeeles pigem vältida (vt Erelt 2011: 23-24). Niisiis võib öelda, et TULEVIKU tekkepind on eesti keeles olemas olnud ning saksa keele mõju on tulevikukonstruktsioonide kasutussagedust suurendanud.

\subsection{Tulevikukonstruktsioon saama $+\mathrm{V}_{\text {ma }}$ vanas kirjakeeles}

XVI-XII ja XIX sajandi kirjakeeles on tulevikku väljendav saama $+\mathrm{V}_{\text {ma }}$ konstruktsioon sagedane (vt ka Habicht 2001: 168-172; Penjam 2008: 265), seda alates XVII sajandi esimesest poolest, kui põhjaeesti kirjakeeles levis saksa werden-futuurumi otsese tõlkevastena saama-tulevikukonstruktsioon. Grammatilise funktsiooni edasiarengu taustaks sobivad võIMALIKKUSE ja RESULTATIIVSUsE tähendusega saama-konstruktsioonid olid selleks ajaks samuti kasutusel.

(29) meije sahme wissist se igkawesse Ello ninck önnistusse sahma.

wir werden gewisz das Ewige Leben vnd die Seligkeit erlangen. (VAKK, Stahl 1641, 445)

'me saame kindlalt igavese elu ja õnnistuse'

Eelnevas lauses on kasutatud saama-tulevikukonstruktsiooni leksikaalse saama-verbiga, mis esineb tähenduses 'omandama'. Sellel kõrge grammatiseerumisastmega konstruktsioonil on eesti keeles ka sobiv lähtekonstruktsioon, mis ei ole siiski vana kirjakeele tekstides sagedane. Lähtekonstruktsioonis väljendub sisuliselt modaalsele lähedane 'takistusest hoolimata võimalikuks saamise', üldisemalt õNNESTUMISE tähendus (vt Habicht, Tragel 2014: 831-833). Vormiliselt annab seda edasi saama-abiverb koos põhiverbi ma-infinitiiviga, st konstruktsiooni vorm on sama mis tulevikukonstruktsiooni puhul, nt

(30) .. temmast [elevandist] sõas ennam abbi sa ollema, sest et jo enne mahhalastakse, enne kui waenlase liggi saab jõudma. (VAKK, Masing 1818, 100) 
Ehkki täispiibli tõlkimisega seoses arutati ka saama-futuurumi kasutuskõlblikkuse üle ja otsustati seda võõrmõjulist vormi kirjakeeles vältida, leidub väga üksikuid tulevikukonstruktsioone siiski ka esimeses eestikeelses täispiiblis (1739), nt

(31) Se sullane, kes targaste ommad asjad aiab, saab wallitsema perre poia ülle .. (VAKK, Piibel 1739, Op 17:2)

'Sulane, kes oma asju targasti korraldab, [hakkab] valitsema perepoja üle'

Varasemates eesti keele grammatikates on erinevalt tänapäevastest futuurum omaette ajavormina välja toodud ning ka tekstides kasutatakse seda tulevikule viitavates grammatilistes konstruktsioonides sagedasti kuni $\mathrm{XX}$ sajandi alguseni, nt

(32) Lootus on, et eestuleval talvel kool korralikult töötama saab. (AJA1900\ aja0002)

Rahvakeelse saama $+\mathrm{V}_{\text {ma }}$ konstruktsiooni kasutamisele on osutanud ka Julius Mägiste, kes on toonud näiteid varasematest tekstidest ja grammatikatest, nt kui saan tulema, siis olen pühiks teil; lammas saab kandma (Mägiste 1936: 77). Nendestki näidetest ilmneb seos resultatiivse tähendusega.

Mägiste toob näiteid ka Eesti murretes esineva saama-potentsiaali kohta, nt ta sai papp olema 'ta võis (ilmselt) papp olla', ta sai seda ütlema 'ta võis (vist) seda öelda', sii sai olema sii küla 'see võis olla see küla' (Mägiste 1936: 78). Uiboaed kirjeldab selliseid konstruktsioone enda uuritud murdematerjalis kui mineviku sündmuse kontekstis tulevikulisusele osutavaid. saama-verb on sellistes konstruktsioonides imperfekti vormis. (Uiboaed 2013: 154) Seda tüüpi kasutusjuhud võiks siinse töö terminites lugeda episteemiliste hulka. Just sellistelt rahvapärastelt konstruktsioonidelt on TULEVIKULE üleminek ka loogilist grammatiseerumiskäiku silmas pidades igati ootuspärane.

\subsection{Tulevikukonstruktsioon saama $+V_{\text {tud }}$ vanas kirjakeeles}

Lisaks tavapärasele aktiivi futuurumile leidub vanas kirjakeeles alates esimestest kirjapanekutest hulgaliselt näiteid futuurumi passiivi vormide kasutamise kohta. Seda võib arvatavasti taas põhjendada religioossete tekstide stiilikaanoniga ning varasemate tekstide tõlkelise päritoluga. Eeskujutarindiks on siin saksa werden + mineviku partitsiip, nt Stahlil münno Tüttar sahp sest Kurratist kurjast waiwatut. Meine Tochter wird vom Teuffel übel geplaget. (VAKK, Stahl 1638, 49) Nii võib juba XVI sajandi lühikestes käsikirjalistes tekstides kohata näiteid saama-passiivikonstruktsioonide kohta (33). Konstruktsioon on väga sage ka XVII (34a) ja XVIII sajandi (34b) kirjakeeles.

(33) Jsa mede, egæs sina olet, taiva sise, Pühæt sako sinu nimi ..

'Meie isa, kes sa oled taevas, pühitsetud saagu sinu nimi' (VAKK, Völcker 1585, 1)

(34a) Kui taema kaas say maha mattetuth, sysz say taema vche wöra Hauwa sisse pantuth. (VAKK, Müller 1601/4, 11)

'Kui ta sai maha maetud, sai ta pandud võõrasse hauda'

(34b) Ussu läbbi langsid Jeriko Mürid mahha/ kui seitse Päwa nende ümber sai käidud. (VAKK, UT 1715, He 11:30) 
Sellised konstruktsioonid lõimuvad tihti pidama-konstruktsiooniga ning on kasutusel veel ka XIX sajandi lõpu tekstides (näites 35 on pidada-vorm evidentsiaalsuse marker).

(35) Kuninga proua ei suutwat ennast liigutada ning pidada woodisse ja woodist wälja kantud saama. (AJA1890\val0604)

saama-passiivikonstruktsioonid on grammatiliselt keerukad tervikud, mis võivad lähtuda rahvakeeles olemas olnud aktiivivormis resultatiivsetest konstruktsioonidest AGENT + saama $+\mathrm{V}_{\text {nud. }}$. Tulevikus lõpetatava tegevuse tähendus on ka aktiivikonstruktsioonis olemas, mistõttu võis kirjakeel selle hõlpsasti omaks võtta.

Saksa ja inglise keele mineviku kesksõnu (millel puuduvad selgelt aktiivi ja passiivi eristavad vormid) on nimetatud resultatiivseteks kesksõnadeks (Haspelmath 1994). Võib oletada, et eesti keele tud-partitsiibi resultatiivne kasutus on kujunenud saksa keele toel. Seda tõendavad selgelt vanema eesti kirjakeele tekstid, kus resultatiivsed partitsiibikonstruktsioonid on saamaverbiga seoses kõige sagedamad. Eriti puudutab see $t u d$-partitsiibiga konstruktsioone, mis väljendavad tegevuse teostumist koos viitega tulevikulisusele (nt 36).

(36) Ja kui nemmad pissut sawad karristatud, tehhakse neile pärrast rohkeste head .. (VAKK, Piibel 1739, Trk 3:5)

Tuleviku abiverbina kasutamine on saama-verbi siinses artiklis käsitletud funktsioonidest kõige kõrgemal grammatiseerumisastmel (AEG kui grammatiline kategooria), ehkki nagu eespool näidatud, on eesti kirjakeele algusaegade kontaktimõjuline grammatiseerumine tulevikukonstruktsioonide esinemissagedust kunstlikult suurendanud. Siiski on vähemalt saab olema futuurumikonstruktsioon ka tänapäeva eesti keeles produktiivne. Järjest rohkem leidub aga kasutusjuhte ka dünaamiliste verbidega (vt Prass 2011: 42), mis võimaldab arvata, et praegune inglise keele mõju hoiab tuleviku väljendamise malli kirjakeeles alal ja isegi võimendab seda.

\section{Kokkuvõte}

Artiklis andsime ülevaate eesti keele polüseemse saama-verbi grammatiliste funktsioonide kujunemisest. saama on eesti keeles vana ja tänapäevaks pika grammatiseerumistee läbinud verb, mis on algsest liikumistähendusega iseseisvast lekseemist arenenud modaalseks abiverbiks ning futuurumikonstruktsioonides kasutatavaks abiverbiks. saama on nii vanemas kui ka tänapäevases kirjakeeles olnud sagedase kasutusega, seda eriti tänu eri tüüpi grammatilistele funktsioonidele, mida saama-konstruktsioonid väljendavad ja millega on seotud ka eri käändeliste vormidega konstruktsioonid: $m a$-infinitiiv (latiivse lähtetähendusega - seos MUUTUMISEGA, mis on suunatud protsess), $d a$-infinitiiv (objektilise lähtetähendusega - seos OMANDAMISEGA, mis on objektiga seotud protsess), nud-, tud-partitsiibid (resultatiivse lähtetähendusega seos MUUTUMISEGa). 
Grammatilised konstruktsioonid, milles saama esineb

\begin{tabular}{|c|c|c|}
\hline Tähendus & Konstruktsioon & Näide \\
\hline VÕIMALIKKUS & Agent + saama + Teema $+\mathrm{V}_{\mathrm{da}}$ & Nad saavad vilja müüa. \\
\hline VAJALIKKUS & Agent + saama $+\mathrm{V}_{\mathrm{da}}$ & Me ei saa siin olla. \\
\hline TÕENÄOSUS & Agent + saama $+\mathrm{V}_{\mathrm{da}}$ & Me saame näha. \\
\hline TÕENÄOSUS & Agent + saama $+\mathrm{V}_{\mathrm{ma}}$ & $\begin{array}{l}\text { Nad ei saa tagasi } \\
\text { pöörama. }\end{array}$ \\
\hline \begin{tabular}{|l|} 
RESULTATIIVSUS \\
(impersonaalne)
\end{tabular} & Teema + saama $+\mathrm{V}_{\text {tud }}$ & Laul sai/saab lauldud. \\
\hline $\begin{array}{l}\text { RESULTATIIVSUS } \\
\text { (personaalne) }\end{array}$ & Agent + saama $+\mathrm{V}_{\text {nud }}$ & Ta saab söönud. \\
\hline TULEVIK (staatiline) & Teema + saama $+\mathrm{V}_{\mathrm{ma}}+$ Omadus & Kontsert saab olema tore. \\
\hline TULEVIK (dünaamiline) & Agent + saama $+\mathrm{V}_{\mathrm{ma}}$ & Ta saab töötama. \\
\hline
\end{tabular}

saama-verbi keerukat grammatiseerumiskäiku pole senini põhjalikumalt avatud. Seetõttu visandasime siinse käsitluse tarbeks lihtsustatud grammatiseerumisahela, kuhu paigutasime olulisimad leksikaalsed ja grammatilised tähendused, mida saama-verb kannab (vt joonist 1). saama funktsioonide arengut käsitlesime pankrooniliselt, st kasutasime vanu andmeid sünkroonilise kasutuse seletamisel ja tänapäevaseid andmeid varasemate muutuste tõlgendamisel, arvestades seejuures vanimate kirjakeele tekstide tõlkelist algupära.

saama-verbi grammatiseerumine on kulgenud ühelt poolt grammatiseerumise universaalsetele seaduspärasustele vastavalt, st algsest liikumistähendusega leksikaalsest üksusest on erinevate järjest grammatilisemate vaheastmete kaudu kujunenud tuleviku abiverb. Tulevikukonstruktsioon on tänapäeva kirjakeeles produktiivsena kasutusel saab olema ühendis. Hoolimata keelekorralduse vastuseisust on seda tüüpi tulevikukonstruktsioonid levinud ka dünaamilisi tegevusi väljendavate verbidega (saab tegema, saab kavandama). Tuleviku abiverbi kujunemisel on täheldatav ka vana kirjakeele perioodil läbitud kontaktimõjulise grammatiseerumise etapp, kus saksa keele werden-futuurumi eeskujul võeti religioossete tekstide tõlkimisel tekkinud funktsionaalse tühiku täitmiseks kasutusele tõlkemõjuline saama-tulevikukonstruktsioon, mis ei olnud jõudnud keeles loomulikul teel välja areneda. Ka võõrmõjulised tulevikukonstruktsioonid ei tulnud keeles kasutusele tühjale kohale, sest rahvakeeles olid välja kujunenud poolabiverbi saama ja infinitiivi- või partitsiibivormiga konstruktsioonid, mis väljendasid õNNESTUMIST, RESUlTATIIVSUST ja sedakaudu ka viidet tulevikulisusele (saab meile öeldud, töö sai tehtud). Selliste rahvakeelsete konstruktsioonide olemasolu (nt lehm saab lüpsma, kas sa saad juba minema) ühelt poolt ja teisalt saksa keele mõju kinnistasid keeles selliseid grammatilisi konstruktsioone nagu osalejasisese ja osalejavälise võIMALIKKUSE (mees sai sealt läbi pugeda; ta saab selle maha mü̈̈a) ja VAJALIKKUSE (riik ei saa keelduda) väljendamine ning sealt edasi episteemiliste, kogu lausesisu TÕENÄOSUST hindavate konstruktsioonide kujunemine (tema ei saanud see olla). Et kirjakeeles uuendusena kasutusele võetud saama-tulevikukonstruktsioon oli algusest peale väga sage, võisid rahvakeel- 
sed üksikkasutused tagaplaanile jääda ja kirjakeelest kaduda. Tulevik on ka konstruktsiooniliselt (saama-abiverb $+m a$-infinitiiv) selgelt eristunud, selle motivatsioon episteemiliste kasutuste näol avaldub pigem tõlgendustasandil (see saaks teile liiga tegema).

Materjali esitades püüdsime järjestikku paigutada tähenduslikult ja funktsionaalselt kõige tihedamini seotud valdkonnad. Arvatavat grammatiseerumisahelat täpselt järgivat kirjeldust ei olnud võimalik pakkuda, sest grammatiseerumisahel ei ole lineaarne. Materjali analüüsides torkas silma asjaolu, et ÕNNESTUMISE tähendus on saama-verbil kirjakeele dokumenteeritud andmete põhjal otsustades pidevalt olemas olnud (vt Habicht, Tragel 2014). Episteemilist kasutust esindavad nii $\mathrm{V}_{\mathrm{da}}$ kui ka $\mathrm{V}_{\mathrm{ma}}$ konstruktsioonid, millest viimane võimaldab ümbertõlgendust ka tüüpiliseks tulevikukonstruktsiooniks.

Kui vanemas eesti kirjakeeles on saama põhiliselt kasutusel resultatiivsetes ja tulevikukonstruktsioonides, siis tänapäeva eesti keeles on kõige sagedasemad osalejavälist võIMALIKKUST ja vAJALIKKUST väljendavad modaalkonstruktsioonid. Seejuures torkab modaalkonstruktsioonide juures silma nende eituslembus. Seda saab seletada interpersonaalse, kommunikatiivse eesmärgiga: keelekasutaja vahendab vastuvõtjale teate sellest, et ta ei tule mingil põhjusel toime ja ootab reaktsiooni või otsest abi.

Artiklis osutame ka sellele, et eesti saama-passiivikonstruktsioon kannab endas tüpoloogiliselt nii nn GET-passiivi kui ka BECOME-passiivi omadusi ja tähendusi, sest ka leksikaalsel saama-verbil on need mõlemad tähendused olemas. Seda (mitte tingimata ajalises järgnevuses kujunemist) peaks kajastama ka meie visandatud ahel joonisel 1, mis algab LIIKUMISE ja õNNESTUMISE kui leksikaalsete lähtetähendustega ja jaguneb konstruktsiooni sisu ja vormi arvestades kaheks OMANDAMISE ja MUUTUMISE tähenduse lahknemisega. OMANDAMISE tähendusega on seotud võImALIKKus ja osalejaväline vaJALIKKUs; MUUTUMISE tähendusega osalejasisene VAJALIKKUS, TÕENÄOSUS, RESULTATIIVSUS ja TULEVIK. Ahela funktsioonide hargnemine kajastab ühtlasi ka vormilist eristust: OMANDAMISE tähendusega algava haru modaalkonstruktsioonid vormistatakse eesti keeles $d a$-infinitiivis põhiverbiga, MUUTUMise tähendusega harus, mis lõpeb tulevikUGA, aga $m a$-infinitiivis põhiverbiga. Omaette funktsiooni, RESULTATIIVSUST, esindavad mineviku partitsiipidega -nud ja -tud moodustatud konstruktsioonid.

Eesti keele saama-verbiga vormistatud erinevad konstruktsioonid vajaksid tulevikus siiski tunduvalt täpsemat kasutuspõhist analüüsimist, kui see praeguses esmases kvalitatiivses sissevaates võimalikuks sai. Süsteemne korpuseuuring võiks siinsete arutluskäikude kinnitamiseks või kummutamiseks mõndagi huvitavat pakkuda.

Külli Habichti uurimistööd on toetanud Euroopa Liit Euroopa Regionaalarengu Fondi kaudu (Eesti-uuringute tippkeskus) ning Eesti Haridus- ja Teadusministeeriumi uurimisprojekt PUT475 „Kirjakeele morfosüntaksi varieerumise integreeritud mudel: pilootuuring eesti keele näitel”. 


\section{Võrguviited}

CHILDES. http://childes.psy.cmu.edu/data/other/

Eesti kirjakeele korpus. http://www.cl.ut.ee/korpused/baaskorpus

Eesti murrete korpus. http://www.murre.ut.ee/murdekorpus/

EKSS = Eesti keele seletav sõnaraamat. http://www.eki.ee/dict/ekss/

etTenTen veebilehtede korpus. http://www2.keeleveeb.ee/dict/corpus/ettenten/ about.html

Tartu Ülikooli vana kirjakeele korpus (VAKK). http://www.murre.ut.ee/vakkur/ Korpused/korpused

\section{Kirjandus}

Ahrens, Eduard 1853. Grammatik der Ehstnischen Sprache Revalschen Dialektes. Zweite umgearbeitete Auflage. Reval: In Commission bei Kluge und Ströhm.

A u w er a, Johan van der, Plungi a n, Vladimir 1998. Modality's semantic map. Linguistic Typology, nr 2, lk 79-124.

Dahl, Östen 2000. The grammar of future time reference in European languages. - Tense and Aspect in the Languages of Europe. Toim Östen Dahl. Berlin: Mouton de Gruyter, lk 309-328.

Di e d r i c h s e n, Elke 2012. What you give is what you get? On reanalysis, semantic extension and functional motivation with the German bekommen-passive construction. - The Art of Getting: GET verbs in European languages from a synchronic and diachronic point of view. Toim Alexandra N. Lenz, Gudrun Rawoens. Special Issue of Linguistics, kd 50, nr 6, lk 1163-1204.

Erelt, Mati 2003. Syntax. - Estonian Language. (Linguistica Uralica Supplementary Series 1.) Toim Mati Erelt. Tallinn: Estonian Acadamy Publishers, lk 93-129.

Erelt, Mati 2011. Lause õigekeelsus. Juhatused ja harjutused. Tallinn: Emakeele Selts.

Erelt, Mati 2013. Eesti keele lauseõpetus. Sissejuhatus. Öeldis. (Tartu Ülikooli eesti keele osakonna preprindid 4.) Tartu.

Ha bi cht, Külli 2001. Eesti vanema kirjakeele leksikaalsest ja morfosüntaktilisest arengust ning Heinrich Stahli keele eripärast selle taustal. (Dissertationes philologiae estonicae Universitatis Tartuensis 10.) Tartu: Tartu Ülikooli Kirjastus.

Ha bi cht, Külli, Tragel, Ilona 2014. Verbiga saama väljendatud leksikaalsed kategooriad ja konstruktsioonid. - Keel ja Kirjandus, nr 11, lk 826-844.

H a b i c h t, Külli, Pi i r oj a, Piret, Tr a ge l, Ilona 2015. Eesti võtma-tuleviku lugu. - Emakeele Seltsi aastaraamat 60 (2014). Tallinn: Teaduste Akadeemia Kirjastus, lk 19-50.

Has pelm ath, Martin 1994. Passive participles across languages. - Voice: Form and Function. Toim B. Fox, P. Hopper. Amsterdam-Philadelphia: Benjamins, lk 151-177.

Heine, Bernd 1993. Auxiliaries: Cognitive Forces and Grammaticalization. New York: Oxford University Press.

Heine, Bernd, Kuteva, Tania 2002. World Lexicon of Grammaticalization. Cambridge: Cambridge University Press. 
Heine, Bernd, Kuteva, Tania 2003. On contact-induced grammaticalization. Studies in Language, kd 27, nr 3, lk 529-572.

Heine, Bernd, Kuteva, Tania 2005. Language Contact and Grammatical Change. Cambridge: Cambridge University Press.

H o p p e r, Paul J. 1991. On some principles of grammaticalization. - Approaches to Grammaticalization. Kd I. Toim Elizabeth Closs Traugott, Bernd Heine. Amsterdam-Philadelphia: Benjamins, lk 17-36.

Kangasniemi, Heikki 1992. Modal Expressions in Finnish. (Studia Fennica: Linguistica 2.) Helsinki: Finnish Literature Society.

Kehayov, Petar, Torn-Leesik, Reeli 2009. Modal verbs in Balto-Finnic. Modals in the Languages of Europe. (Empirical Approaches to Language Typology 44.) Toim Björn Hansen, Ferdinand de Haan. Berlin-New York: Mouton de Gruyter, lk 363-401.

Kletten berg, Reet 2007. Permissiivkonstruktsioon eesti kirjakeeles. Magistritöö. Käsikiri TÜ eesti ja üldkeeleteaduse instituudis. Tartu.

Lindström, Liina, Tragel, Ilona 2007. Eesti keele impersonaali ja seisundipassiivi vahekorrast adessiivargumendi kasutuse põhjal. - Keel ja Kirjandus, nr 7, lk 532-553.

Lind strö m, Liina, Tra g e 1, Ilona 2010. Possessive perfect construction in Estonian. - Folia Linguistica, kd 44, nr 2, lk 371-400.

Metslang, Helle 1994a. Temporal Relations in the Predicate and the Grammatical System of Estonian and Finnish. (Oulun yliopiston suomen ja saamen kielen laitoksen tutkimusraportteja 39.) Oulu: University of Oulu dissertation.

Mets lang, Helle 1994b. Eesti ja soome - futuurumita keeled? - Keel ja Kirjandus, nr 9, lk 534-547; nr 10, lk 443-453.

Metslang, Helle 1997. Eesti keele ja teiste soome-ugri keelte futuurumi arenguid. - Keel ja Kirjandus, nr 4, lk 226-231.

Metslang, Helle 2011. Some grammatical innovations in the development of Estonian and Finnish: Forced grammaticalization. - Linguistica Uralica, nr 4, lk 241-256.

Mägiste, Julius 1936. Eesti saama-futuurumi algupärast ja tarvitamiskõlblikkusest. - Eesti Keel, nr 3, lk 65-92.

Nolan, Brian 2012. The get constructions of Modern Irish and Irish English: getpassive and get-recipient variations. - The Art of Getting: GET verbs in European languages from a synchronic and diachronic point of view. Toim Alexandra N. Lenz, Gudrun Rawoens. Special Issue of Linguistics, kd 50, nr 6, lk 1111-1161.

Pajus alu, Renate, Tragel, Ilona, Veis mann, Ann, Vija, Maigi 2004. Tuumsõnade semantikat ja pragmaatikat. (Tartu Ülikooli üldkeeleteaduse õppetooli toimetised 5.) Tartu: Tartu Ülikooli Kirjastus.

Penjam, Pille 2008. Eesti kirjakeele $d a$ - ja $m a$-infinitiiviga konstruktsioonid. (Dissertationes philologiae estonicae Universitatis Tartuensis 23.) Tartu: Tartu Ülikooli Kirjastus.

Pra s s, Kerli 2011. saama- ja hakkama-tulevik tänapäeva eesti kirjakeeles. - Oma Keel, nr 2, lk 39-47.

Ross, Kristiina 2013. Vanad uuendused lõuna- ja põhjaeesti keeles. - Emakeele Seltsi aastaraamat 58 (2012). Tallinn: Teaduste Akadeemia Kirjastus, lk $210-224$.

S a ukk on en, Pauli 1966. Itämerensuomalaisten kielten tulosijainfinitiivirakenteiden historiaa I. Helsinki: Suomalais-Ugrilainen Seura. 
Sweets er, Eve E. 1990. From Etymology to Pragmatics: Metaphorical and Cultural Aspects of Semantics Structure. (Cambridge Studies in Linguistics 54.) Cambridge: Cambridge University Press.

Tr a ge l, Ilona 2003. Eesti keele tuumverbid. (Dissertationes linguisticae Universitatis Tartuensis 3.) Tartu: Tartu Ülikooli Kirjastus.

Tragel, Ilona 2004. Tuumverbi ja $d a$-infinitiivi ühendid. (Tartu Ülikooli eesti keele õppetooli preprint I.) Tartu.

Tr a g el, Ilona 2007. Modaalverbide saama/saada ja võima/voida vastandkasutus eesti ja soome keeles. - Grammatika és kontextus - új szempontok az uráli nyelvek kutatásában. (Urálisztikai tanulmányok 17.) Toim M. Csepregi, V. Masonen. Eötvös Loránd Tudományegyetem, Finnugor Tanszék, Budapest, 2004. április 4-7. Eötvös Loránd University, lk 331-338.

Tra ge 1, Ilona, Ha bi cht, Külli 2012. Grammaticalization of the Estonian saama 'get'. - The Art of Getting: GET verbs in European languages from a synchronic and diachronic point of view. Toim Alexandra N. Lenz, Gudrun Rawoens. Special Issue of Linguistics, kd 50, nr 6, lk 1371-1412.

Tra u g tt, Elizabeth Closs 1989. On the rise of epistemic meanings in English: An example of subjectification in semantic change. - Language, kd 65, nr 1, lk $31-55$.

Ui b o a ed, Kristel 2013. Verbiühendid eesti murretes. (Dissertationes philologiae estonicae Universitatis Tartuensis 34.) Tartu: Tartu Ülikooli Kirjastus.

\section{The verb saama 'to get' in grammatical constructions}

Keywords: polysemy, grammaticalisation, construction, verb saama 'to get', written Estonian

In the present article an overview is given of the development of the grammatical functions of the Estonian polysemous and polyfunctional verb saama 'get; can, become'. The article is a follow-up to an overview of the lexical usages of the same verb (Habicht, Tragel 2014). saama is an old Estonian verb with a long history of grammaticalization from a lexical motion verb to a modal auxiliary and to an auxiliary verb used in future constructions. The verb saama is frequent both in early and modern written Estonian, in particular due to the various grammatical functions expressed by saama-constructions. The Estonian saama-constructions contain non-finite verb forms such as the - $m a$ infinitive (the original function of which is lative, referring to change as a directed process), - $d a$ infinitive (the original function of which is object, referring to acquisition as an object-bound process), and -nud, -tud participles (the original function of theirs is resultative, referring to a change). The Estonian passive construction of saama is a typological vessel of the properties and functions of both GET-passive and BECOME-passive, because the full verb of saama used to have and still has both of the meanings. Considering the use of the word and its constructions from $16^{\text {th }}$ to $21^{\text {st }}$ centuries, we suggest a grammaticalisation chain for the Estonian saama.

Ilona Tragel (b. 1968), PhD, University of Tartu, Institute of Estonian and General Linguistics, Associate Professor of General Linguistics; Estonian Institute / Beijing Foreign Studies University, Lecturer of Estonian, ilona.tragel@ut.ee

Külli Habicht (b. 1964), PhD, University of Tartu, Institute of Estonian and General Linguistics, Senior Researcher, kulli.habicht@ut.ee 